\title{
HVMANITAS
}

\section{Pausanias and the roman conquerors}

Autor(es): $\quad$ Pereira, Maria Helena da Rocha

Publicado por: Faculdade de Letras da Universidade de Coimbra, Instituto de Estudos

URL

persistente:

Clássicos

DOI: $\quad$ DOI:http://dx.doi.org/10.14195/2183-1718_63_9

Accessed : $\quad$ 26-Apr-2023 11:00:52

A navegação consulta e descarregamento dos títulos inseridos nas Bibliotecas Digitais UC Digitalis, UC Pombalina e UC Impactum, pressupõem a aceitação plena e sem reservas dos Termos e Condições de Uso destas Bibliotecas Digitais, disponíveis em https://digitalis.uc.pt/pt-pt/termos.

Conforme exposto nos referidos Termos e Condições de Uso, o descarregamento de títulos de acesso restrito requer uma licença válida de autorização devendo o utilizador aceder ao(s) documento(s) a partir de um endereço de IP da instituição detentora da supramencionada licença.

Ao utilizador é apenas permitido o descarregamento para uso pessoal, pelo que o emprego do(s) título(s) descarregado(s) para outro fim, designadamente comercial, carece de autorização do respetivo autor ou editor da obra.

Na medida em que todas as obras da UC Digitalis se encontram protegidas pelo Código do Direito de Autor e Direitos Conexos e demais legislação aplicável, toda a cópia, parcial ou total, deste documento, nos casos em que é legalmente admitida, deverá conter ou fazer-se acompanhar por este aviso. 
humanitas

Vol. LXIII

2011 


\title{
PAUSANIAS AND THE ROMAN CONQUERORS
}

\author{
M. H. Rocha Pereira \\ Universidade de Coimbra
}

\begin{abstract}
After a brief account of the renewed interest in Pausanias' work, special attention is paid to the Periegetes' attitude towards the Roman rulers. Several passages referring to the Roman conquerors and their behaviour towards the Greeks are discussed, not only those about Augustus or Nero and the ones concerning the so-called "good emperors", but also the vexed questions of the interpretation of Vespasian's sentence on the freedom of Greece and of the meaning of the judgement passed over Sulla's behaviour towards the Greek people.
\end{abstract}

Key-words: Pausanias' Periegesis, Augustus, Nero, good emperors, Vespasian, Sulla's behaviour, theatres.

\section{Resumo}

Após uma breve resenha do renovado interesse pela obra de Pausânias, analisa-se com especial atenção a atitude do Periegeta para com os governadores romanos. Discutem-se diversos passos referentes aos conquistadores romanos e ao seu comportamento para com os Gregos, não só os referentes a Augusto ou Nero e os que dizem respeito aos chamados "bons imperadores", mas também as discutidas questões da interpretação da frase de Vespasiano sobre a liberdade da Grécia e do significado do juízo emitido sobre o comportamento de Sula para com o povo grego.

Palavras-chave: A Periegese de Pausânias, Augusto, Nero, os bons imperadores, Vespasiano, o comportamento de Sula, teatros. 
Everybody acknowledges that at least since the last decades of the twentieth century the studies on Pausanias have gained a new interest, so that not only new critical editions have been published or are in progress, but many other scholars brought important contributions for a better understanding of his many-sided Description of Greece. Let us single out, among many important books, the volume that Christian Habicht has produced under the title Pausania's Guide to Ancient Greece for the Sather Classical Lectures in 1982 (University of California Press, 1985, simultaneously with its German translation) and the proceedings of the meeting of the Hardt Foundation (Pausanias Historien, 1994, published two years later) and of Neuchatel and Fribourg Universities, 1998 (Éditer, traduire, commenter Pausanias en l'an 2000, 2001), both of the last mentioned titles pointing to the two main research areas of interest at the present time.

Concerning the French and Italian editions in progress, ${ }^{1}$ particular emphasis must also be given to the wealth of archaeological and epigraphic information they provide us with.

On the other hand, the inclusion of our writer in the Second Sophistic, though it may still have some supporters, needs not detain us here. ${ }^{2}$

As to viewing Pausanias as a historian, I quite agree with Musti's 1994: 9 proposal to place the Periegetes' work under the head "discorso storico", a position which Lafond 1994: 204 reinforces with the idea of a "psychological dimension" which adequates the text to "the mentality of his readers".

This is an approach which will help us, I hope, to understand Pausanias' opinions - and sometimes also omissions - on the Roman conquerors. ${ }^{3}$ As a matter of fact, he lived in a time when almost three centuries had elapsed since the fall of Corinth, and most of the great encomia of the Roman conquests had been written by other Greeks, like Dionysios of Halicarnassus and Appianus and, before them, by one of the greatest historians, Polybius. Besides that, not many decades before Pausanias himself, Plutarch had written a half-philosophic small treatise on De Romanorum Fortuna, as-

${ }^{1}$ Casevitz, Pouilloux, Chamoux et alii (Paris: Les Belles Lettres 1992 -). Musti, Beschi et alii (Milano: Fondazione Lorenzo Valla 1982 - ).

${ }^{2}$ See Habicht 1985:139, where he says that the labels "Sophie" and "Buntschriftsteller", "sind glücklicherweise heute kaum noch in Gebrauch". See also Pretzler 2007: 26-27.

${ }^{3}$ Hutton 2008: 622, n. 1 provides a list of sixteen works dealing with the subject, starting with Regenbogen's entry RE Suppl. 8, 1956: 1069-78. 
king whether Tyche or Arete had prevailed on the creation of such memorable achievements. Whether the treatise is complete or not, published during his lifetime of left unpublished, need not concern us here.

But this is not the sort of questions Pausanias asks. Although his Periegesis starts abruptly at the Sunion promontory, without giving any indication of the purpose and method of his book, his readers can soon find out his guiding principles. Among many scattered sentences which, to my mind, leave no doubt on the matter, I would choose two different ones. The first one comes at the end of the story of Pyrrhus, 'the first to cross the Ionian sea from Greece to attack the Romans' ${ }^{4}(1.12 .1)$ in 280 B.C. There he compares the accounts of the Argives and Lyceas with the one given by Hieronymus the Carcian and concludes: 'A man who associates with royalty cannot help being a partial historian'5 (1.13.9). The other one is particularly relevant, in so far as it confirms the importance Pausanias gives to autopsy, when, after stating that the grave of Tantalus on Mount Sipylus is worth seeing, he specifies (2.22.3): i̇ $\omega$ v oîd $\alpha$ ('I know because I saw it'). It is also worth noting that such words come immediately after laying aside the discussion on the contradictory legends about the various identifications of that particular Tantalus. ${ }^{6}$

Another important point in his approach to history is his well-known rationalism. A few examples concentrate upon Book 2, for instance when he writes at the very beginning: 'That Corinthus was a son of Zeus, I have never known anybody say seriously, except the majority of the Corinthians'. The same attitude is to be found when he refers later on in the same book to the spring behind the temple of Aphrodite on the summit of the Acrocorinthus as being a gift of Asopus to Sisyphus, in return for his information about the rape of his daughter by Zeus, a treason that might have caused the king's punishment in Hades (2.5.1); and then he adds: ö $\tau \omega \iota$

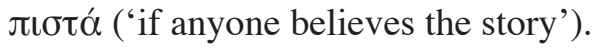

${ }^{4}$ Throughout this paper all translations are taken from W. H. S. Jones' edition for the Loeb Classical Library (London - Cambridge, Mass. 1956-61), unless otherwise stated.

5 The interest of this text for defining the historical method of our writer has already been pointed out by Musti and Beschi in their Lorenzo Valla edition (Milano, vol. 1, 1982: 305).

${ }^{6}$ About the origin of Tantalus, Musti and Torelli say in their commentary (Milano, vol. 2, 1986: 286): "È un tipico esempio di abilità espositiva e, insieme, di economia di parole e di spazio". 
Later on, when he comes to a place called Delta, he flatly refuses to discuss the origin of that name, because he cannot accept the traditional accounts, and such a statement is put into two significant words (2.21.1): Ėxòv $\pi \alpha \varrho i ́ \eta \mu$. Again in the same chapter, when speaking about 'a mound of hearth, in which they say lies the head of the gorgon Medusa', he adds (2.21.5): 'I omit the miraculous but give the rational part of the story about her'.

A rationalist explanation of the metamorphosis of Procne and Philomela into a swallow and a nightingale is attempted in 1.41.9: 'the note of these birds is plaintive and like a lamentation'.

Most important in this field is his treatment of the attitude of the Roman conquerors, among them of the personality of Nero, which has been discussed by almost all the scholars who have dealt with Pausanias, and also provides us with a most significant insight into his way of understanding history.

That Nero was one of the philhellenic emperors, frequently referred to in the Periegesis, is a well-known fact. Also well known is Pausanias' understandable preference for such emperors. His attitude towards Nero has nevertheless given way to much discussion among scholars, and one has but to look through the important paper on "Pausanias et les empereurs romains", published by Jacquemin ${ }^{7}$, for a summary of the main opinions, and also for the differences between the Periegetes' account and the testimonia of other Greek and Roman writers.

Anyhow, Nero's removal of precious statues, like the one of Odysseus within the Altis (5.25.8) or the treasures dedicated by Mycythus also at Olympia (5.26.3) are stated without comment. Not so the removal of the image of Praxiteles' Eros, a theft originally committed by Gaius, then restored by Claudius, and stolen a second time by Nero (9.27.3-4). Both the first and the third mentioned emperors sinned against the god, says Pausanias, and therefore had to be punished. Nero, 'in addition to his violence to his mother, committed accursed and hateful crimes against his wedded wives'. On the other side, although he does not mention the troubled relations between the emperor and the Delphic oracle referred to by other sources, as Jacquemin wisely adverts, ${ }^{8}$ Pausanias clearly sums up his condemnation of the theft of precious works in a memorable phrase

\footnotetext{
${ }^{7}$ Ktema 21 (1996) 29-42, particularly 33-35.

${ }^{8}$ Ktema 21 (1996) 34 and n. 38.
} 
which all the historians of Greek art know by heart (10.7.1): 'It was fated too that Delphi was to suffer from the universal irreverence of Nero, who robbed Apollo of five hundred bronze statues, some gods, some men'.

Passing over other minor references to Nero and the comments they have aroused, I would like to concentrate now upon some other matters. One of them is the omission of the Emperor's participation in the Olympic games in 65 A.D. followed by six victories, although we do not know the exact relationship of these events to the three golden crowns he dedicated to Zeus at the sanctuary, referred to in 5.12.8 . Another point is also the at least apparent omission, this time at the very beginning of Book 2, of the speech of the emperor delivered at the Isthmian games in 66/7 A.D., according freedom to the province of Achaia. One must emphasize that besides references to it by Tacitus (Annales 3.50), Suetonius (Nero 24) and Plinius ( $H . N$. 4.22), an important part of the proclamation has been preserved and published and much discussed as well, throughout the latest decades ${ }^{10}$. I called this an apparent omission because there is an implicit reference to the event much later on, in a most celebrated chapter of Book $7^{11}$.

Let us remember first of all that a very large part of this book (more than half of it) is concerned with what Moggi, in the introduction to his edition, after comparing it to Polybius' account, calls a "riscrittura originale e feconda di una pagina storiografica di relevante interesse"12.

Now this part includes, as is well known, an encomium of Ionia, described as 'a land of wonders that are but little inferior to these of Greece' (7.6.1), and also a summary of the last years of Greek independence (7.17.1-4) with special emphasis on events like the devastation of Argos and the ascendancy of Macedonia. Incidentally let us remember that a choice between the Macedonian and the Roman power seemed impossible to avoid, as demonstrated in chapter 8 of the same book.

But let us return to the chapter we have been considering, since it is the one where a most famous statement concerning Nero turns up: how 'he gave the Roman people the very prosperous island of Sardinia in exchange for Greece, and then bestowed upon the later complete freedom'. Imme-

\footnotetext{
${ }^{9}$ On the subject see Jacquemin1996: 34 with n. 41.

${ }^{10}$ On the text and commentaries see Jacquemin 1996: 36 with n. 43.

11 7.1.3. On this topic see Arafat 1996: 140-3.

${ }^{12}$ Milano (2000) XIII.
} 
diately afterwards comes the author's own interpretation of some striking differences in the behaviour of the Emperor along his lifetime, an interpretation for which he finds support in a quotation of Plato's Republic 491c: 'When I considered this act of Nero it struck me how true is the remark of Plato, the son of Ariston, who says that the greatest and most daring crimes are committed, not by ordinary men, but by a noble soul ruined by a perverted education'. The only reminiscence of Nero's declaration of freedom as a real gift which immediately followed the statement that 'the Greeks, however, were not to profit by the gift' only suggests, as noticed by Arafat 1996:141 "a genuine enthusiasm for the idea in Pausanias, albeit combined with a sense of inevitability that it did not succeed". There follows the no less famous order of the emperor, Vespasian, when seeing the Greeks involved, once more, in a civil war, that they had to pay tribute and be subject to a governor, since 'the Greek people had forgotten how to be free'. That is the statement which Arafat 1996: 141 and 155-6 qualifies, not without reason, as "colourless", mostly when compared to the reaction of other writers.

The case with Nero, who was nevertheless one of the philhellenic emperors, is a special one. Then, towards the end of the century, came the four Antonines, the so called "the good emperors", who are deservedly praised in the Periegesis, Hadrian most of all. As a matter of fact, encomiastic references to this emperor are scattered throughout most of the book, particularly in the first one. Let us start by singling out three examples from that book: in 3.2, it is said that in Athens, near the Stoa, 'stands Zeus of freedom, and the Emperor Hadrian, a benefactor to all his subjects and especially to the city of Athens'; later on, in 5.3, when coming to speak about the Athenian eponymoi, he counts him as one of those who had a tribe named after him, since he had been a most religious man, 'and contributed very much to the happiness of his various subjects', 'never voluntarily entered upon a war', built many sanctuaries of the gods and gave the bounties to Greek cities and sometimes even to foreigners who asked him, all these acts being inscribed in the Athenian sanctuary common to all gods.

Many other praises are to be read throughout this as well as other books, but perhaps the greatest of them all is the one that occurs near the end of Book 1 (36.3) in a context which at first sight might be interpreted as a failure in the Roman government, whereas, as a matter of fact, it means an enhancement negatively formulated. That is, to my mind, what happens 
in the sentence about the Megarians being punished by the wrath of the two goddesses, 'for they are the only Greeks that not even the emperor Hadrian could make more prosperous'.

Let us also point out that all Greek cities are said to have dedicated statues to the emperor (1.5.5) and that one of them was erected in the cella of the Parthenon (1.24.7). Hadrian is also mentioned as the emperor who made Athens flourish again, two centuries after the devastation caused by Sulla (1.20.7). In order to understand the full meaning of the statement, one must remember that it comes immediately after the much discussed sentence about Sulla's behaviour towards the Athenian people, which he calls 'so savage as to be unworthy of a Roman' (and here I give Jones' translation

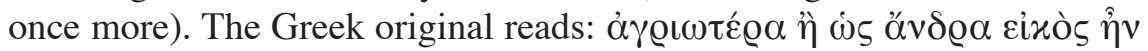

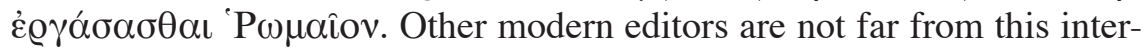
pretation. Pouilloux, for example, in the Budé edition by Casevitz 1992:6667, translated it like this: 'une cruauté plus terrible que celle que l'on eût dû attendre d'un Romain'. But a somewhat different nuance seems to underlie Musti's rendering in the Lorenzo Valla edition, 1982:107: 'più crudele di quanto ci si potesse aspettare da un romano'. Anyhow, like Jones and unlike such scholars as Habicht 1985:122, n. 16, Bowie 1996: 218 thinks that the term 'cruelty', used by both of them, "translates the Greek less well than 'savagery". According to him, Pausanias means that "Sulla's savagery is surprising and untypical", or, as Bowersock 1985:710 wrote, "most uncharacteristic of the Romans generally". This is also, to my mind, the full meaning of the sentence under discussion.

Coming back to the philhellenic emperors, there is no need to emphasize the place Pausanias allots to Augustus, despite the preference he sometimes showed for the Greeks who had been on his side on the occasion of the battle off the cape of Actius Apollo (4.31.1-2). He even excuses him for carrying away offerings and images of the gods, saying that he "only followed a custom in vogue among the Greeks and the barbarians of old" (8.46.1-5). In 3.11.4, when describing the temple in the market-place in Sparta, a brief comparison between Caesar and his adopted son gives pride of place to the latter, because he 'put the empire on a firmer footing, and became a more famous and a more powerful man than his father'.

Much else might be said on this topic, but to me it seems preferable to turn to a much vexed question. The Periegesis has often been called a guide-book. As a matter of fact, its description of places and monuments has proved invaluable for the identification of archaeological sites. One 
needs only to remember the excavations in the Athenian agora to prove it. On the other side, its description of the paintings of the Lesche of the Cnidians in Delphi has been, up to now, an invaluable substitute for understanding the style of Polygnotus. But does this mean that, although writing mainly for a Greek audience, as Bowersock rightly says, "Pausanias neglects to make appropriate comparisons with other people's achievements, when making them, his only purpose is to extol Greek superiority"13? His discussion about the Stymphalïan birds in 8.22 .5 might lead us to think so, since he concludes that the name of those birds, though not the original one, prevailed owing to "the fame of Heracles and the superiority of the Greeks over the foreigner' ${ }^{14}$. This attitude seems to be contradicted by his remark in 9.36.5, that 'the Greeks appear apt to regard with greater wonder foreign sights than sights at home' and his complaint that 'distinguished historians have described the Egyptian pyramids with the minutest detail', whereas 'they have not made even the briefest mention of the treasury of Minyas and the walls of Tiryns, though these are no less marvellous'. But he is careful, before praising the symmetry and beauty of the theatre of Epidaurus, to acknowledge that generally speaking 'the Roman theatres are far superior to those anywhere else in their splendour' (2.27.5).

Another point concerning Pausanias' attitude towards Roman domi-

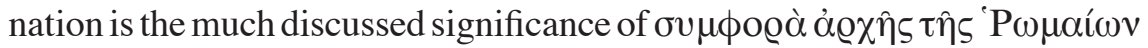
(8.27.1). The text, as it stands, seems to mean «the disaster of Roman rule», that is to say «the disaster consisting of Roman rule». But nearly two centuries ago Clavier suggested a very simple emendation which changes the sense of the whole, by inserting the preposition غ̇ंí before $\alpha \varrho \chi \eta ิ \varsigma$, a usage that has parallels in the Periegetes' style. This has been approved by Palm ${ }^{15}$ and accepted by modern editors of Pausanias ${ }^{16}$. Other scholars, like Habicht 1985:121, Arafat 1996:202, Pretzler 2007:162, n. 85 also agreed. On the other side, Hutton (2008) CQ, N.S., 58, 622-87, after presenting a

${ }^{13}$ Bowersock 1985: 710.

${ }^{14}$ See the Budé edition by Casevitz, Jost and Marcadé (Paris, vol. 8, 1998: 202), who on this topic refer the reader to J. Heer, La Personnalité de Pausanias, Paris 1979: 64-5, which I have been unable to see.

${ }^{15}$ Rom, Römertum und Imperium in der griechischen Literatur der Kaiserzeit, Lund 1959: 74.

${ }^{16}$ Like my own Teubner edition (Leipzig, vol. 2, ${ }^{2} 1990$ ); Casevitz, Jost and

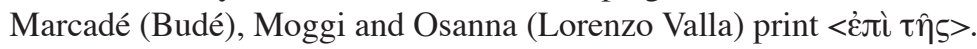


very complete discussion of the question, favours an unemended text, although excluding the view that Pausanias might be anti-Roman.

Many other examples might be adduced. But the ones presented here may be enough to show that Pausanias lived in a world where political and cultural distinction have lost sense ${ }^{17}$, and, on the other side, as Bowersock said, "this intercourse between Greeks and Romans not only affected the course of Greek literature and rhetoric; it unified East and West"18. This cultural union is a message with a special relevance to our own times. May we never forget its meaning.

\section{Bibliography}

Alcock, Susan E., Cherry, John F. and Elsner, Jas (eds.) (2001), Pausanias. Travel and Memory in Roman Greece, Oxford: University Press.

Arafat, K. W. (1996), Pausanias' Greece. Ancient Artists and Roman Rulers, Cambridge: University Press.

Bowersock, G. W. (1965), Augustus and the Greek World, Oxford: University Press.

- (1985), "Pausanias" in The Cambridge History of Classical Literature, vol. 1, Cambridge: University Press.

BowIE, E. L. (1996), "Past and Present in Pausanias", in Entretiens sur l'Antiquité Classique de la Fondation Hardt, tome 41, Genève: 207239.

Casevitz, M., Pouilloux, J., Chamoux, F. et alii (1992 - ) eds., Pausanias, Description de la Grèce, Paris: Les Belles Lettres.

Haвicht, Christian (1985), Pausanias' Guide to Ancient Greece, University of California Press (German translation: Pausanias und seine Beschreibung Griechenlands. München: Beck).

Hutton, William (2005), Describing Greece. Landscape and Literature in the Perigesis of Pausanias, Cambridge: University Press.

- (2008), "The Disaster of Roman Rule: Pausanias 8.27.5", CQ, N.S., 58: 622-637.

${ }^{17}$ On this topic see, among others, Lafond, 1996: 174-5.

${ }^{18}$ Oxford 1965: 123. 
Jones, W. H. S. (1959), Pausanias. Description of Greece, with an English translation in 4 vols. with a companion vol., Loeb Classical Library. London - Cambridge, Mass.

Lafond, Y. (1996), "Pausanias et l'Histoire du Péloponnèse depuis la Conquête Romaine" in Entretiens sur l'Antiquité Classique de la Fondation Hardt, tome 41, Genève: 167-205.

- (2001), "Lire Pausanias à l'Époque des Antonins. Réflexions sur la place de la Périégèse dans l'Histoire Culturelle, Religieuse et Sociale de la Grèce Romaine" in Knoepfler, D., et Piérart, M. (eds.), Éditer, Traduire, Commenter Pausanias en l'an 2000, Genève: Droz.

Musti, D., Beschi, L. et alii (1982 - ) eds., Pausania. Guida della Grecia, Milano: Fondazione Lorenzo Valla.

Pretzler, Maria (2007), Pausanias. Travel writing in Ancient Greece, Bristol: Classical Press.

Pritchett, W. Kendrick (1998), Pausanias Periegetes. Amsterdam: Gieben. 